\title{
First description of the male of Castianeira arnoldii Charitonov, 1946 (Aranei: Corinnidae) from Central Asia, and a survey of Palaearctic Castianeira
}

\author{
Описание самца Castianeira arnoldii Charitonov, 1946 (Aranei: \\ Corinnidae) из Средней Азии и обзор палеарктических Castianeira
}

\author{
Yuri M. Marusik ${ }^{1,2} \&$ Kirill G. Mikhailov ${ }^{3}$ \\ Ю.М. Марусик ${ }^{1,2}$, К.Г. Михайлов ${ }^{3}$
}

\begin{abstract}
${ }^{1}$ Institute for Biological Problems of the North RAS, Portovaya Str. 18, Magadan 685000 Russia. E-mail: yurmar@mail.ru Институт биологических проблем Севера ДВО РАН, ул. Портовая, 18, Магадан 685000 Россия.

${ }^{2}$ Zoological Museum, University of Turku, FI-20014 Turku, Finland.

${ }^{3}$ Zoological Museum of the Moscow State University, Bolshaya Nikistkaya Str. 6, Moscow 125009 Russia. E-mail: mikhailov2000@gmail.com Зоологический музей МГУ, ул. Б. Никитская, 6, Москва 125009 Россия.
\end{abstract}

KEY WORDS: Aranei, spiders, Corinnidae, Central Asia, Uzbekistan, Turkmenistan. КЛЮЧЕВЫЕ СЛОВА: пауки, Corinnidae, Средняя Азия, Узбекистан, Туркменистан.

ABSTRACT. The male of Castianeira arnoldii Charitonov, 1946, is described for the first time, and the female is redescribed. The species is distributed from western Turkmenistan to eastern Uzbekistan. $C$. arnoldii is likely to be a senior synonym of C. rugosa Denis, 1958, described from northern Afghanistan. All 13 species of Castianeira known from Palaearctic and adjacent regions of South-East Asia have been listed. In Eurasia, the highest species diversity for this genus is in China.

РЕЗЮМЕ. Впервые описан самец и переописана самка Castianeira arnoldii Charitonov, 1946. Выснено, что вид обитает от западной Туркмении до восточного Узбекистана. Предполагается, что $C$. arnoldii является старшим синонимом C. rugosa Denis, 1958, описанной из северного Афганистана. Перечислены 13 видов рода Castianeira, известных из Палеарктики и прилежащих регионов Юго-Восточной Азии. Наибольшее видовое разнообразие рода в Евразии обнаружено в Китае.

\section{Introduction}

Castianeira Keyserling, 1879, is an ant-mimicking spider genus with 131 species [Platnick, 2009] distributed all over the globe except for Australia and adjacent islands. It belongs to Castianerinae, a subfamily erected by Reiskind [1969] and contains currently at least 15 genera [Deeleman-Reinhold, 2001]. The largest generic diversity of the subfamily, 13 genera, is observed in South-East Asia.

Eurasian Castianeira are restricted to the southern regions with a subtropical climate. The northernmost localities lie in the Iberian Peninsula, Israel, Uzbekistan and South Korea [Marusik, 2009]. Palaearctic Castianeira has never been revised. Only Castianeira arnoldii Charitonov, 1946, is known from Central Asia. It was described on the basis of subadult male and subadult female from Uzbekistan. Until recently [Marusik, 2009] it was known only from the original description. When Marusik [2009] published the first description of the female of $C$. arnoldii, the second author provided set of specimens from different Central Asian states containing both males and females. The goal of this paper is description of the male for the first time, and giving the distribution of the species.

\section{Material and methods}

The specimens were photographed using an Olympus SZX16 stereomicroscope and an Olympus Camedia C-520 camera. The images were montaged using "CombineZM" image stacking software. Photographs were taken in dishes with paraffin on the bottom. Different sizes of holes were made in the paraffin to keep the specimens in the correct position. The soft tissue on the epigyne was macerated with $\mathrm{KOH}$. All measurements are given in $\mathrm{mm}$. All material belongs to the Zoological Museum of the Moscow State University.

Species description

Castianeira arnoldii Charitonov, 1946

Figs 1-6.

C. a. Charitonov, 1946: 28, f. 52 (subadult $+\&$ subadult $\sigma^{7}$ )

C. a.: Marusik, 2009: 66, f. 1-6 (). 

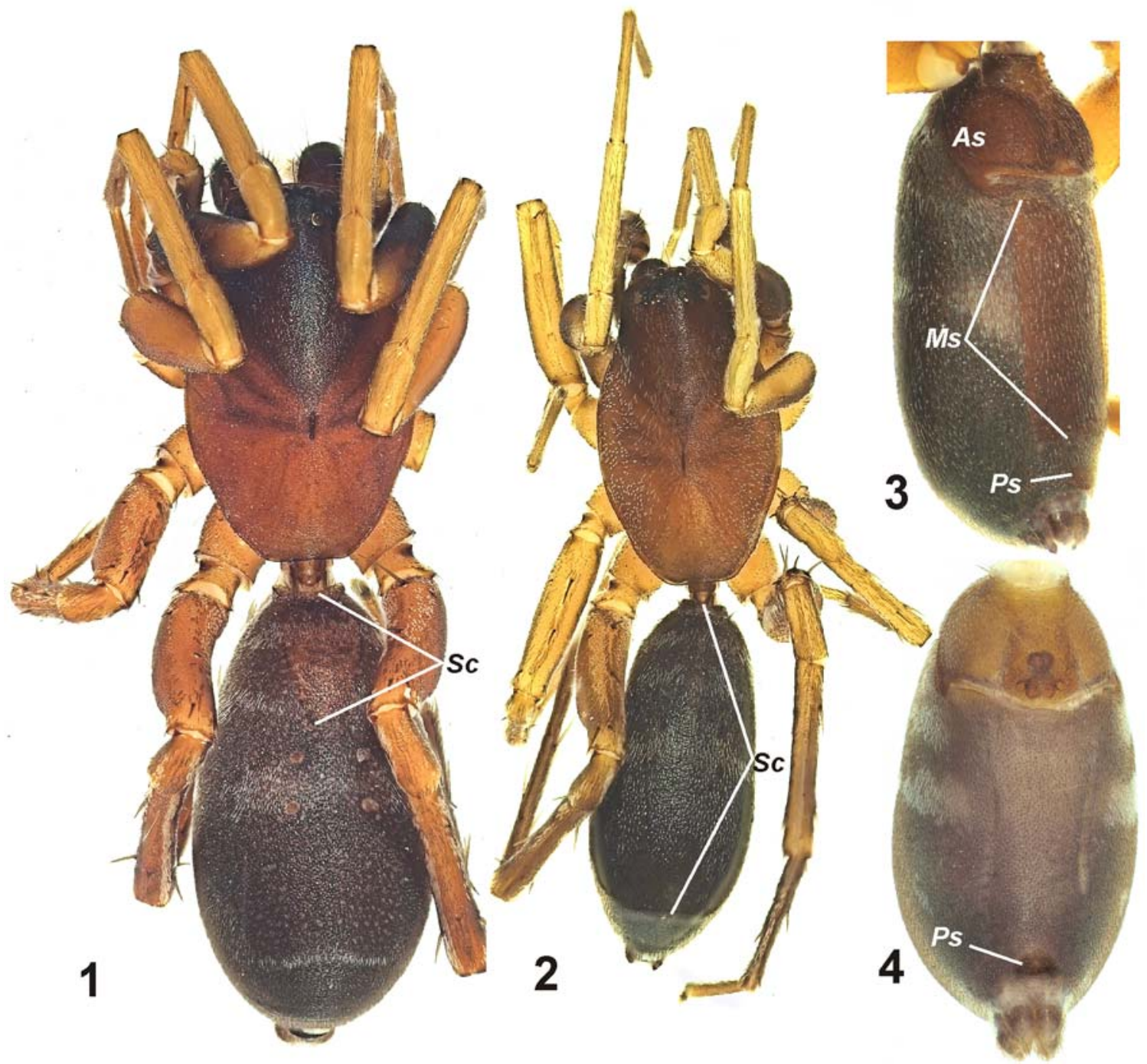

Figs 1-4. Somatic characters of Castianeira arnoldii: 1-2 - female and male, dorsal; 3 - male abdomen, ventro-lateral; 4 - female abdomen, ventral. Abbreviations: $A s$ - anterior ventral scutum; $M s$ - median ventral scutum; $P s$ - posterior ventral scutum; $S c$ - dorsal abdominal scutum.

Рис. 1-4. Соматические признаки Castianeira arnoldii: 1-2 - самка и самец, дорсально; 3 - брюшко самца, вентролатерально; 4 - брюшко самки, вентрально. Сокращения: $A s-$ передний вентральный скутум; $M s-$ срединный вентральный скутум; $P S$ - задний вентральный скутум; $S c$ — дорсальный брюшной скутум.

MATERIAL EXAMINED. TURKMENISTAN: $20^{x} 0^{x} 1$ \& 3 juv, $25 \mathrm{~km}$ upstream along Sumbar River East of Kara-Kala, canyon, 1.02.1982 (K.G. Mikhailov); 1 O$^{7}$, SE Karakum Desert, Repetek, on sand, 7.05.1982 (V. Krivokhatski); $1 \sigma^{7}$, Gasan-Kuli Reserve, left bank of M[aloye] Delili Lake, 24.01.1982 (K.G. Mikhailov); 1 q 1 juv, Gasan-Kuli Reserve, Delili Kordon, 28.01.1981 (K.G. Mikhailov); $1 \odot^{7}$, Amudarya Reserve, 16-18.05.1987 (F. Zaleev). UZBEKISTAN: $40^{7} O^{7} 3$ 우, Bukhara Area, $33 \mathrm{~km}$ SE of Bukhara, 39 $35^{\circ} \mathrm{N}$, $64^{\circ} 43^{\prime} \mathrm{E}, 19.05 .1994$ (A.A. Zyuzin); 1 ㅇ, 1 subad.,+ 1 subad. $0^{7} \& 1$ juv., Surkhandarya Area, Termez Dist., W bank of Uchkyzyl reservoir, ca. $1.5 \mathrm{~km}$ E of Kaftarkhana, $350 \mathrm{~m}, 37^{\circ} 20^{\prime} 58^{\prime \prime} \mathrm{N} 67^{\circ} 12^{\prime} 30^{\prime \prime} \mathrm{E}$, 28.04.2002 (A. Gromov). TAJIKISTAN ${ }^{1}$ (?): $1 \mathrm{O}^{7}$, Varganza Vil., forestry, in gebril's burrow, 8.06 .1978 (V.I. Ovtsharenko).

${ }^{1}$ It seems that this record refer to eastern Uzbekistan.
DIAGNOSIS. C. arnoldii is most similar to $C$. flavimaculata $\mathrm{Hu}$, Song \& Zheng, 1985 (cf. Figs 254KL, 255A-B in Song et al., 1999), known from the southern half of China. The females of two species can be easily separated by the smaller copulatory openings in C. arnoldii separated by 4 diameters (vs. less than 2 diameters in C. flavimaculata) and the shorter insemination ducts in $C$. arnoldii. Males of two species have indistinguishable emboli, but can be separated by proportions of tegulum (longer in Chinese species) and shape of seminal ducts. Loop of seminal duct in $C$. arnoldii is almost perpendicular to the axis of the tegulum, while in Chinese species it is slanting. 

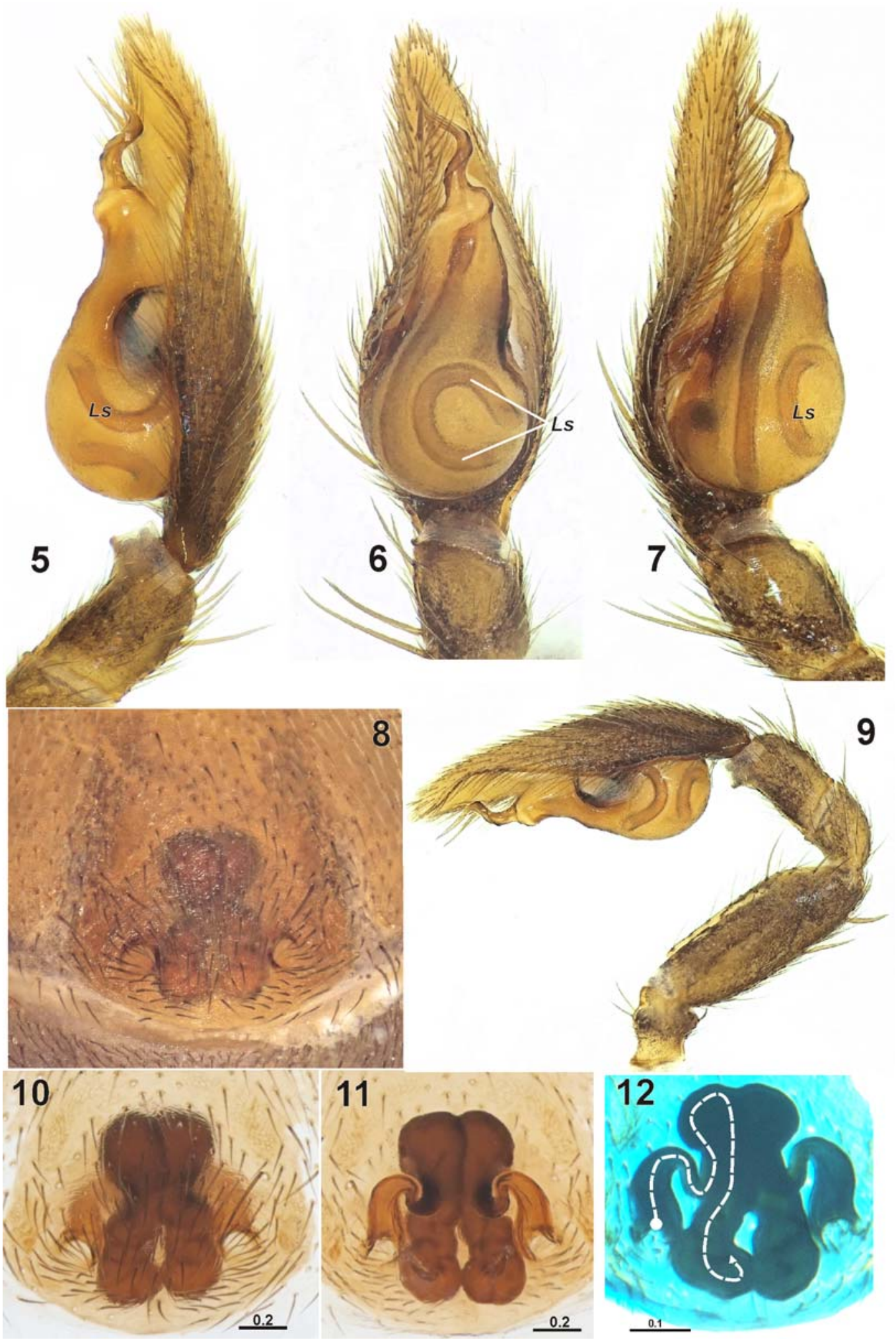

Figs 5-12. Copulatory organs of Castianeira arnoldii: 5-7 - male palpus, retrolateral (5), ventral (6) and prolateral (7); 8 - intact epigyne, ventral; 9 - whole male palp, retrolateral; 10-11 - epigyne after maceration, ventral and dorsal; 12 - epigyne after maceration showing course of insemination duct, ventral. Abbreviation: $L s$ - seminal loop.

Рис. 5-12. Копулятивные органы Castianeira arnoldii: 5-7 — пальпус самца, ретролатерально (5), вентрально (6) и пролатерально (7); 8 - неочищенная эпигина, вентрально; 9 - пальпа самца, ретролатерально; $10-11$ - эпигина после очистки, вентрально и дорсально; 12 - эпигина после очистки, показан ход оплодотворительного канала, вентрально. Сокращение: $L s-$ петля семявыводящего канала. 


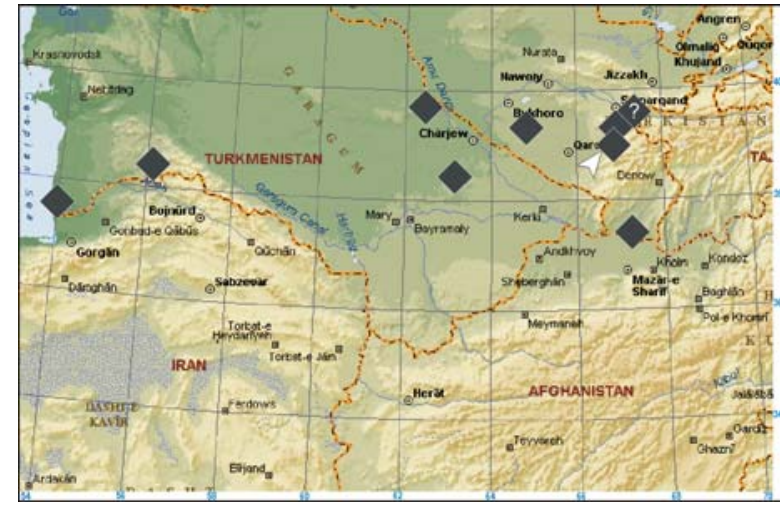

Fig. 13. Distribution of Castianeira arnoldii. Arrow indicate the type locality.

Рис. 13. Распространение Castianeira arnoldii. Типовое местонахождение указано стрелкой.

DESCRIPTION. Female. Described in details by Marusik [2009]. Total length 7.71-8.0. Carapace 3.253.45 long, 2.00-2.15 wide, cephalic and anterior part of thoracic region almost black, rest of carapace redbrownish (Fig. 1). Chelicerae, maxilla and labium black to dark brown. Basal two thirds of femur I black, apical third yellowish. Abdomen violet-black, with three wide, light transverse bands in frontal half, and small Vshaped stripe in posterior half. Bands and stripe are distinctly visible in juveniles only. Anterior part of abdomen with small scutum (Sc, Fig. 1). Venter of abdomen with median band (between epigastral fold and spinnerets) lighter than rest of abdomen, and pair of transverse lateral median bands. Small scutum $(P S)$ present just in front of spinnerets (Fig. 4). Its shape and size is the same as in male. Spination of $\sigma^{7}$ and + :

\begin{tabular}{|l|l|l|l|}
\hline & \multicolumn{1}{|c|}{ Femur } & \multicolumn{1}{c|}{ Tibia } & \multicolumn{1}{c|}{ Metatarsus } \\
\hline I & $3 \mathrm{~d}, 1 \mathrm{pa}$ & $3-3 \mathrm{v}$ & $2-2 \mathrm{v}$ \\
\hline II & $3 \mathrm{~d}, 1 \mathrm{pa}$ or $2 \mathrm{p}$ & $3-3 \mathrm{v}$ or $2-3 \mathrm{v}$ & $2-2 \mathrm{v}$ \\
\hline III & $3 \mathrm{~d}, 2 \mathrm{p}$ & $2 \mathrm{p}, 2 \mathrm{r}, 3-3 \mathrm{v}$ & $3 \mathrm{p}, 3 \mathrm{r}, 3-3 \mathrm{v}$ \\
\hline IV & $3 \mathrm{~d}, 2 \mathrm{p}$ & $2 \mathrm{p}, 2 \mathrm{r}, 3-3 \mathrm{v}$ & $3 \mathrm{p}, 3 \mathrm{r}, 3-3 \mathrm{v}$ \\
\hline
\end{tabular}

Epigyne as in Figs 8, 10-12. At first look it is possible to consider the adult female as juvenile, because the copulatory openings are so small and the epigynal plate is of the same color as the rest of abdomen. The epigynal plate is fused with the book-lungs and forms a pre-epigastral scutum extending from the petiolus to the epigastral fold. The epigynal openings are small and separated from each other by 3.5-4 diameters, and by one diameter from the epigastral fold; insemination ducts wide near copulatory opening gradually tapering, terminal part of insemination duct 3 times thinner than near copulatory openings; insemination duct joins to receptacula at mid part; receptacula long, with widened ends, anterior parts heavily sclerotized and adjoining each other.

Male. Total length 5.75-6.5. Carapace 2.5-3.0 long, 1.60-1.75 wide. Colouration as in female, but difference between dark cephalic part and lighter thoracic part less distinct (Fig. 2). Some males may have almost the whole carapace dark. Abdomen with large dorsal scutum which covers almost whole abdomen (Fig. 2). Venter of abdomen with long and thin median scutum $(M s)$ running from epigastral fold to almost small scutum $(P S)$ in front of spinnerets (Fig. 3). Scutum near spinnerets has the same shape as in female.

Male palp as in Figs. 5-7, 9, tegulum twice as long as wide; embolus 2.5 shorter than tegulum, seminal loop almost perpendicular to the tegulum axis.

DISTRIBUTION. This species is known from Turkmenistan to Tajikistan. The northernmost locality lies in Turkmenistan almost on $40^{\circ} \mathrm{N}$ longitude. The present record from Tajikistan (Varganza) most probably refer to eastern Uzbekistan. Locality with name Vargnaza was not found on maps. Collector (indicated on the label) was not V.I. Ovtsharenko (Ovtsharenko, personal communication). He visited Tajikistan later in June, and his field-book lacks data about any name similar to Varganza.

COMMENTS. C. rugosa Denis, 1958, described from southern Afghanistan (Pirzada = Pir Zadeh, $\left.31^{\circ} 38^{\prime} \mathrm{N}, 65^{\circ} 03^{\prime} \mathrm{E}\right)$ on the basis of two females is a possible junior synonym of $C$. arnoldii. The figure of the epigyne provided by Denis [1958] is similar to that in $C$. arnoldii. For definite decision, examination of $C$. rugosa type material is necessary.

\section{Discussion}

Platnick [2009] indicate occurrence of 13 Castianei$r a$ species in the Palaearctic Region and adjacent Southeast Asia. This genus has never been revised in the Old World, but only in the New World. Species occurring in the Palaearctic Region and South-East Asia can be split into three groups according to their distribution: 1) West Palaearctic or Mediterranean (4 species: $C$. antinorii (Pavesi, 1880) $\left(\bigcirc^{\top}+\right)$ - Algeria, Tunisia, Sudan, Egypt; $C$. badia (Simon, 1877) $\left(\bigcirc^{\top}+\right)$ - Spain; C. munieri (Simon, 1877) $\left(\bigcirc^{\top}\right)$ - Morocco, Algeria; C. drassodidoides Strand, 1915 (juv.) - Israel); 2) Central Asia: C. arnoldii Charitonov, $1946\left(\sigma^{\top}+\right)$ Uzbekistan, Turkmenistan and Tajikistan; C. rugosa Denis, $1958(+)$ - southern Afghanistan; and 3) Far East Palaearctic: C. arcistriata Yin et al., 1996 (+); C. daoxianensis Yin et al., 1996 (+); C. flavipatellata Yin et al., $1996\left(\bigcirc^{7}\right)$; C. trifasciata Yin et al., $1996\left(\bigcirc^{7}\right)-$ all from Hainan; C. flavimaculata $\mathrm{Hu}$, Song \& Zheng, $1985\left(\sigma^{\top}+\right)$ - Guangdong, Zhejiang, Hunan, Hubei, Sichuan (China); C. hongkong Song, Zhu \& Wu, 1997 $\left(O^{7}\right)$ - Hong Kong; C. shaxianensis Gong, 1983 $\left(\mathrm{O}^{\top}+\right)$ - China (Fujian), Korea, Japan. C. flavimaculata occurs also outside Palaearctic.

Judging from the distribution, $C$. drassodidoides known only by juvenile specimen from Israel, could belong to $C$. antinorii known from adjacent Egypt.

Of the four species described from Hunan, China, two are known by females, one by male, and one species is known by both sexes. It is very likely that $C$. trifasciata known by male only, can be conspecific 
with $C$. arcistriata or $C$. daoxianensis known by females.

ACKNOWLEDGEMENTS. We thank Seppo Koponen for allowing the use equipment in Zoological Museum of the University of Turku. Alexander Gromov (Almaty) helped us to locate type locality of $C$. rugosa. Vladimir I. Ovtsharenko (New York) and Boris A. Korotyaev (St. Petersburg) helped us with search of Varganza locality. English of the final draft was kindly checked by Robin Leech. This work was supported in part by the RFFI grant \# 09-04-01365-a.

\section{References}

Charitonov D.E. 1946. [New forms of spiders of the USSR] // Izvestiya estestvenno-nauchnogo Instituta pri Molotovskom
[Permskom] Gosudarstvennom Universitete imeni M. Gor'kogo. Vol.12. No.3. P.19-32 [in Russian, with English summary]. Deeleman-Reinhold Ch. 2001. Forest spiders of South East Asia. Leiden - Boston - Koln: Brill.591 p., 8 pl.

Denis J. 1958. The $3^{\text {rd }}$ Danish expedition to Central Asia. Zoological results. 22. Araignees (Araneida) de l'Afghanistan // Vidensk. Meddr. dansk naturh. Foren. Bd.120. S.81-120.

Marusik Yu.M. 2009. On Central Asian Castianeira arnoldii Charitonov, 1946 (Araneae, Corinnidae), earlier known from juvenile specimens // Zootaxa. No.2226. P.66-68.

Platnick N.I. 2009. The World Spider Catalog, Version 9.5. American Museum of Natural History, online at http:// research.amnh. org/entomology/spiders/catalog/index.html (Accessed 6 April 2009).

Reiskind J. 1969. The spider subfamily Castianeirinae of North and Central America (Araneae, Clubionidae) // Bull. Mus. Comp. Zool. Vol.138. No.5. P.163-325.

Song D.X., Zhu M.S., Chen J. 1999. The Spiders of China. Shijiazhuang: Hebei Science and Technology Publishing House. 640 pp. 